\begin{tabular}{cc}
\hline Revista de & Journal of Integrated \\
GESTÃO COSTEIRA Integrada COSTAL ZONEMANAGEMENT \\
\hline \hline
\end{tabular}

\title{
Tide and Tidal Currents in the Cape Verde Archipelago *
}

\author{
Nilton Gomes $^{\circledR}$, a ; Ramiro Neves $^{\mathrm{a}}$; Isabella Ascione Kenov; ${ }^{\mathrm{a}}$ Francisco Javier Campuzano ${ }^{\mathrm{a}}$; Ligia Pinto ${ }^{\mathrm{a}}$
}

\begin{abstract}
The hydrography and oceanography in deep ocean areas are expensive if based only upon fieldwork and, as a result, countries with smaller financial resources have few data from in situ measurements. This work aims to contribute to demonstrate that based on little local information it is possible to increase our knowledge through the use of numerical models. This paper describes a study of the tidal propagation in the Cape Verde Islands region and the currents induced by the tide assesses the importance of the wind for the circulation using the numerical model MOHID in a two-dimensional mode. The bathymetric data were extracted from the database of NASA SRTM 30 (Shuttle Radar Topography Mission) and the coast line was extracted from the database of NGDC (National Geophysical Data Center). The tide along the oceanic boundary of the model was imposed using the results from the FES2004 model and the wind was imposed using the GFS (Global Forecasting System) meteorological model results. The modeling system is based on a regional scale model with a spatial step of $6 \mathrm{~km}(\mathrm{level} 1)$ in which two models with a spatial step $3 \mathrm{~km}$ (level 2) were fitted to detail the results of the flow in shallower areas of greater morphological complexity where a 2D model and reproduce the effect of wind forcing. Comparison between computed and measured levels in a station located in Palmeira harbor, Sal Island - the only available measuring station - for the year 2000, shows that the model is able to represent the tide in this location. The model results also show that the currents in the shallower areas along and between islands are very sensitive to the atmospheric forcing, suggesting that this sensitivity may extend to zones of greater depth in the presence of vertical stratification.

The residual circulation is the main product of this study with interest for coastal management. It is a completely new result, about which there was no information either from field work or from other models.
\end{abstract}

Keywords: Hydrodynamics, modelling, tides, tidal currents.

\section{RESUMO}

\section{Marés e Correntes de Maré no Arquipélago de Cabo Verde}

A hidrografia e a oceanografia de zonas oceânicas profundas são áreas de trabalho dispendiosas e consequentemente em países com menores recursos financeiros existe normalmente maior carência de dados "in situ". Este trabalho pretende contribuir para demonstrar que com base em pouca informação local é possível aumentar de forma económica o nosso conhecimento através da combinação de dados e de modelos matemáticos. No presente trabalho é efectuado um estudo da hidrodinâmica forçada pela maré na região do Arquipélago de Cabo Verde e é a analisada a sensibilidade da solução ao vento. O trabalho é baseado no modelo numérico MOHID em modo bidimensional. Os dados batimétricos foram extraídos da base de dados da NASA SRTM 30 (Shuttle Radar Topography Mission) e a linha de costa foi extraída da base de dados do NGDC (National Geophysical Data Center). A maré na fronteira oceânica do modelo foi imposta utilizando resultados do modelo global de

\footnotetext{
(a) Corresponding author to whom correspondence should be addressed: Gomes <nilton.gomes@ist.utl.pt>

${ }^{a}$ Instituto Superior Técnico, Universidade de Lisboa, MARETEC, Secção de Ambiente e Energia, Departamento de Mecânica, Av. Rovisco Pais, 1049-001 Lisbon, Portugal.
}

* Submission: 7 JAN 2014; Peer review: 8 FEB 2014; Revised: 19 JUN 2014; Accepted: 5 OCT 2014; Available on-line: 6 OCT 2014
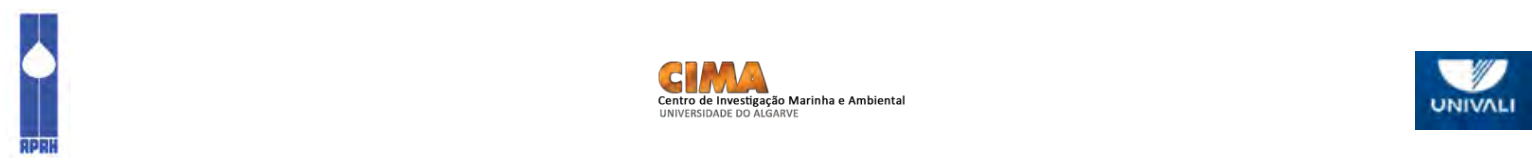
maré FES2004 e o vento foi imposto utilizando resultados do modelo meteorológico GFS (Global Forecasting System). O sistema de modelação é baseado num modelo de escala regional com passo espacial de $6 \mathrm{~km}$ (nível 1), no qual foram encaixados dois modelos de passo espacial de $3 \mathrm{~km}$ (nível 2) para detalhar os resultados do escoamento em zonas de menor profundidade - e maior complexidade morfológica - onde o vento tem afecta o escoamento em toda a coluna de água e pode ser representado por um modelo $2 \mathrm{D}$.

Os níveis de maré calculados pelo modelo foram comparados com os únicos dados de marés existentes, numa estação localizada no Porto de Palmeira, ilha do Sal para o ano de 2000. A comparação dos resultados do modelo com os dados mostra que o modelo representa corretamente os níveis de maré neste local. Os resultados do modelo mostram também que as correntes nas zonas menos profundas - zonas costeiras e canais entre ilhas - são sensíveis ao forçamento atmosférico, sugerindo que esta sensibilidade poderá estender-se a zonas de maior profundidade na presença de estratificação vertical.

A circulação residual em torno das ilhas é o principal produto deste trabalho, com interesse directo para a gestão costeira e sobre a qual não existia nenhuma informação para a região, nem proveniente de medições, nem de outros modelos.

Palavras-chave: Hidrodinâmica, modelação, marés, correntes de maré.

\section{Introduction}

The Cape Verde archipelago located in the Atlantic Ocean, West African coast, is formed by ten islands and belongs to the sub-Sahelian zone. The climate, influenced by the Sahara desert, is dry encompassing two main seasons: a short rain season and a long dry season characterised by constant winds and haze coming from the Sahara desert.

The archipelago was discovered in 1460 by Diogo Gomes at the service of the Portuguese crown and since then, Cape Verde has been at the crossroads of international maritime routes, due to its strategic location. The archipelago also provides bathing areas and attractive tourism activities and its fisheries are an important source of food and jobs. For these reasons increasing attention is being given to the maritime issues by national authorities, although the knowledge about the local ocean circulation in the archipelago of Cape Verde remains scarce. The lack of field surveys and monitoring studies do not allow knowledge building based on data. In this context, numerical models can be used to identify the main processes responsible for the local hydrodynamics and biogeochemical processes creating a background to implement new studies based on field work and on remote sensing.

This paper describes the results of a bi-dimensional (2D) implementation of the numerical model - MOHID (Neves, 2013) - used to simulate the hydrodynamics forced by the tide the in the Cape Verde Archipelago and to assess the role of the wind in shallower areas. Using nested techniques, higher resolution results could be produced to refine the solution in shallow regions of higher topographic variability and/or under higher anthropogenic pressure. Water level data is available at Porto de Palmeira in Sal Island for the year 2000 and this information was used to validate the model results. Wind forcing was specified using GFS wind fields available on the internet (www.nodc.noaa.gov).

The Cape Verde sea is a deep oceanic region and consequently the density stratification of the water column is determines the hydrodynamics of the region as a whole. However islands and the ground elevation between groups of islands are barriers to the tidal propagation that generate important tidal velocities that deserve to be studied. These transient velocities generate residual flow that is the combination of the effects advective inertia and Coriolis inertia (see Huthnance, 1973 and Pingree and Maddock, 1980) that be quantified only by mathematical models. This residual determines the net displacement of anthropogenic discharges and is important for coastal sediment dynamics.

The importance of the residual flow along and between islands associated to the tidal propagation justifies this 2D simulation. This implementation cannot be seen as an ultimate objective, but it is a required step to (a) implement a baroclinic 3D model (it will be nested into this one to get the tide) and (2) to assess the contribution of each forcing effect for the actual flow between and around the islands.

The tide along the open boundary of this implementation was obtained from the model FES2014, which also provides levels inside the modelling domain. Our results do not add much to the levels already provided by FES2014 as the two submodels nested into our main model do not provide heather. The difference between the results of these models are the currents, that are in fact the major contribution for users, whatever they are managers or scientists from other disciplines.

\section{The Study Area}

The Cape Verde archipelago (Figure 1) is located in the Atlantic Ocean on the subtropical region, west of the African coast, between $17^{\circ} 12^{\prime} 15^{\prime \prime} \mathrm{N}$ and $14^{\circ} 48^{\prime} 00^{\prime \prime} \mathrm{N}$ and $22^{\circ} 39^{\prime \prime} 20^{\prime \prime} \mathrm{W}$ and $25^{\circ} 20^{\prime} 00^{\prime} ' \mathrm{~W}$. The archipelago includes ten major islands, nine of which inhabited, and several uninhabited islets, divided in two groups (Figure 1): at north, the Windward Islands ("Ilhas do Barlavento"), and the Leeward Islands ("Ilhas do Sotavento") at the south. The Windward Islands include 


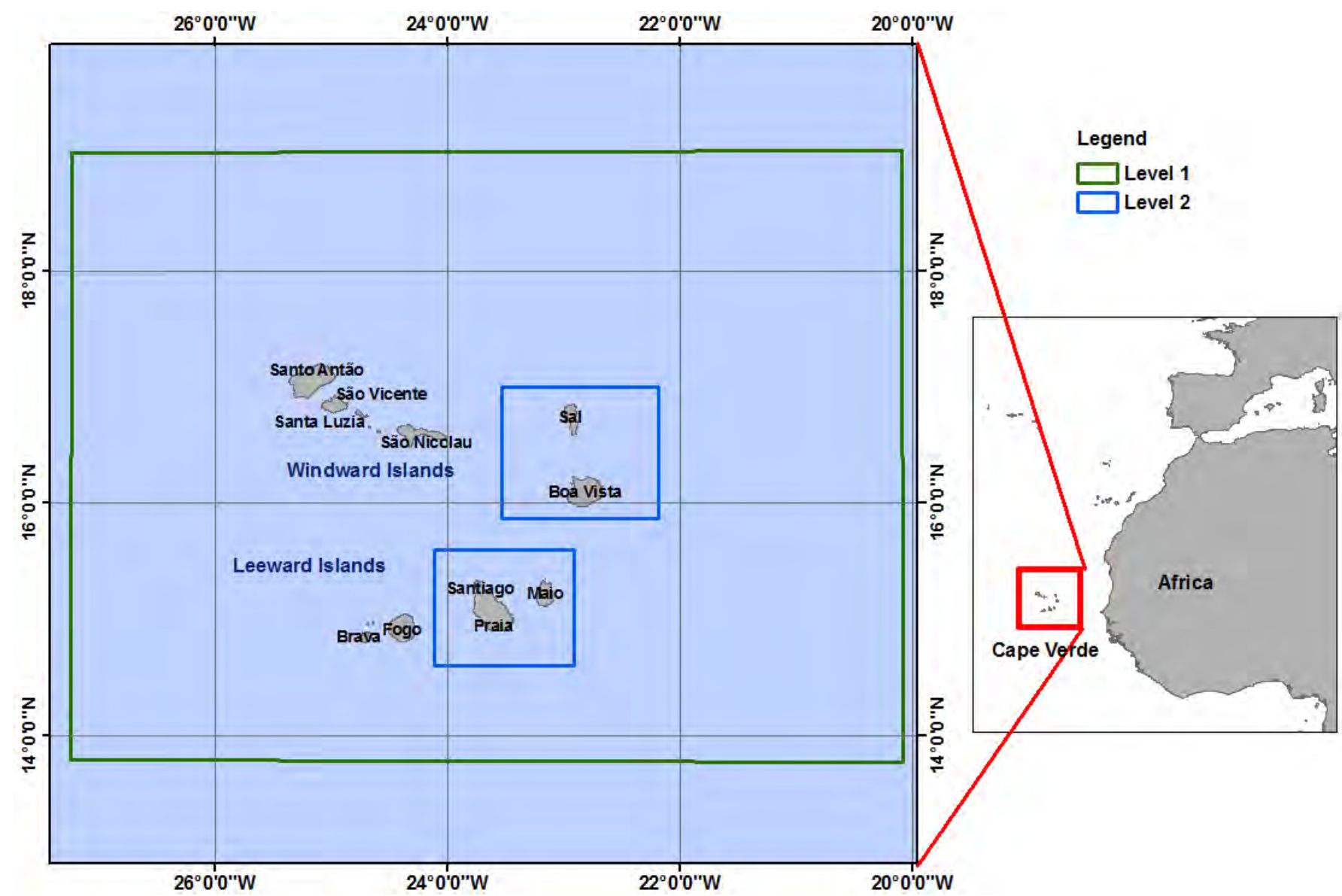

Figure 1 - Geographical location of the archipelago of Cape Verde, Windward and Leeward island groups. The domain of simulation of the Level 1 model is the green rectangle. Blue rectangles identify the regions simulated by nested models.

Figura 1 - Localização geográfica do Arquipélago de Cabo Verde e dos grupos de ilhas de Barlavento e de Sotavento. O rectângulo verde mostra a domínio simulado com o modelo nível 1 e os rectângulos azuis os domínios dos modelos encaixados.

the islands of Santo Antão, São Vicente, Santa Luzia (uninhabited island), São Nicolau, Sal and Boavista. The Leeward Islands include the islands of Maio, Santiago, Fogo and Brava. The archipelago has volcanic origin, with rugged and arid terrain and little vegetation. Most of the islands are mountainous, except the island of Sal, Boavista and Maio, which are flat with long beaches. Weather conditions in the region of Cape Verde are characterized by prevailing northeast trade winds occurring throughout the year. These winds influence intensity and direction of surface currents as well as the sea level height. Higher wind intensities are more frequent in the Leeward Islands than in the Windward Islands (DGA, 2004).

\section{Material and methods}

In the study region the data available is scarce and all the information available was used in the present study. We have used the bathymetry from NASA SRTM (Shuttle Radar Topography Mission) database with spatial resolution of 30 seconds, the tidal data from a station located at Palmeira harbor (Sal Island) and wind velocities measured at a meteorological station located nearby the same harbor. Also the tidal data from the global model FES2004 and the wind fields from GFS model were used. The numerical model used to perform the simulations is the MOHID water modelling system.

Tide data measured in Palmeira harbour (Figure 2), Sal Island are available in the British Oceanographic Data Center (www.bodc.ac.uk). The most recent information dates back to 2000 and the time series covers 8 months (07-04-2000 to 31-12-2000). This data was processed to extract the main tidal components. Table 1 shows amplitude and phase of the most significant tidal components extracted using the T_tide software (Pawlowicz et al., 2002): principal lunar $\left(\mathrm{M}_{2}\right)$, principal solar $\left(\mathrm{S}_{2}\right)$, lunar elliptic $\left(\mathrm{N}_{2}\right)$, luni-solar diurnal $\left(\mathrm{K}_{1}\right)$, principal lunar diurnal $\left(\mathrm{O}_{1}\right)$, luni-solar $\left(\mathrm{K}_{2}\right)$, solar semi-annual (Ssa), principal solar diurnal $\left(\mathrm{P}_{1}\right)$, lunar fortnightly (Mf), quarter-diurnal $\left(\mathrm{M}_{4}\right)$ and lunar monthly $(\mathrm{Mm})$.

Model implementation was challenged by the lack of data and the absence of previous modeling studies at the scale of the archipelago. Two nested modelling levels were used: the level 1 with a coarser grid (green rectangle in Figure 1) uses a $6 \mathrm{~km}$ resolution and covers a domain of about $480000 \mathrm{~km}^{2}$; The level 2 with finer 
Table 1 - Frequency, amplitude and phase of the main tidal components at Palmeira harbour (Sal Island).

Tabela 1 - Frequência, amplitude e a fase das principais componentes da maré no Porto Palmeira (Ilha do Sal).

\begin{tabular}{|c|c|c|c|}
\hline $\begin{array}{c}\text { Tidal } \\
\text { component }\end{array}$ & $\begin{array}{c}\text { Frequency } \\
\left(\mathbf{h}^{\mathbf{1}} \mathbf{)}\right.\end{array}$ & $\begin{array}{c}\text { Amplitude } \\
\mathbf{( m )}\end{array}$ & $\begin{array}{c}\text { Phase } \\
\mathbf{(}^{\circ} \mathbf{)}\end{array}$ \\
\hline $\mathbf{M}_{\mathbf{2}}$ & 0.080511 & 0.296 & 276.69 \\
\hline $\mathbf{S}_{\mathbf{2}}$ & 0.083333 & 0.116 & 317.22 \\
\hline $\mathbf{N}_{\mathbf{2}}$ & 0.078999 & 0.058 & 249.59 \\
\hline $\mathbf{K}_{\mathbf{1}}$ & 0.041781 & 0.052 & 351.32 \\
\hline $\mathbf{O}_{\mathbf{1}}$ & 0.038731 & 0.042 & 260.03 \\
\hline $\mathbf{K}_{\mathbf{2}}$ & 0.083562 & 0.034 & 312.11 \\
\hline $\mathbf{S s a}$ & 0.000228 & 0.028 & 20.39 \\
\hline $\mathbf{P}_{\mathbf{1}}$ & 0.041553 & 0.016 & 337.65 \\
\hline $\mathbf{M f}_{\mathbf{M}}$ & 0.00305 & 0.015 & 19.28 \\
\hline $\mathbf{M}_{\mathbf{4}}$ & 0.161023 & 0.014 & 286.94 \\
\hline $\mathbf{M m}$ & 0.001512 & 0.012 & 346.42 \\
\hline $\mathbf{N} \mathbf{U}_{\mathbf{2}}$ & 0.079202 & 0.012 & 247.09 \\
\hline
\end{tabular}

grids (blue rectangles in Figure 1) uses a $3 \mathrm{~km}$ resolution and cover two areas one of the order of $25000 \mathrm{~km}^{2}$ for the region of the Sal and Boavista Island and another of order of $17000 \mathrm{~km}^{2}$ for the region of Santiago and Maio Island.

Tides were imposed at the open boundary of Level 1 using results from the global tide model FES2004 (Lyard et al., 2006). The two nested models use the levels and velocities computed by Level 1 to specify initial and boundary condition values. Atmospheric forcing was imposed on both modelling levels using
GFS model (Center, 2003) results. The inverted barometer method was used to specify the atmospheric pressure at Level 1. A relaxation condition with an exponential decay over ten cells was used to avoid reflections at the border between the nested models and the Level 1 model. The simulation was performed for a period of two months between April and May 2000. A model spin-up of one month was considered and the model results analyses is performed only for the month of May.

Figure 2 shows the bathymetry of the Level 1 model showing the underwater connection between groups of islands and the vicinity of deep ocean depths between islands. The location of the Palmeira harbour (green point), the fixed buoy (blue point, latitude $16^{\circ} 45^{\prime} 22^{\prime \prime}$ $\mathrm{N}$, longitude $23^{\circ} 3^{\prime} 47^{\prime \prime} \mathrm{W}$ ) where water level data was collected and the weather station where the wind observations were obtained (latitude $16^{\circ} 43^{\prime} 48^{\prime}, \mathrm{N}$, longitude $22^{\circ} 57^{\prime} 3^{\prime}$ ' $\mathrm{W}$, height $54 \mathrm{~m}$ [www.tutiempo. net]) are also shown in Figure2.

Figures 3 compares the water level reconstructed using the tidal harmonics obtained from the Palmeira Port buoy data (dots) with the water level extract from the FES2004 model (line) for a point with the same location of the buoy for the May month. The analysis shows globally a good agreement between the two time series, although in some days differences of the order of $10 \mathrm{~cm}$ can be observed. The correlation coefficient between the two series is $94.48 \%$ (Figure 4) showing that a tidal model forced by the FES2004 results is also expected to have good results.

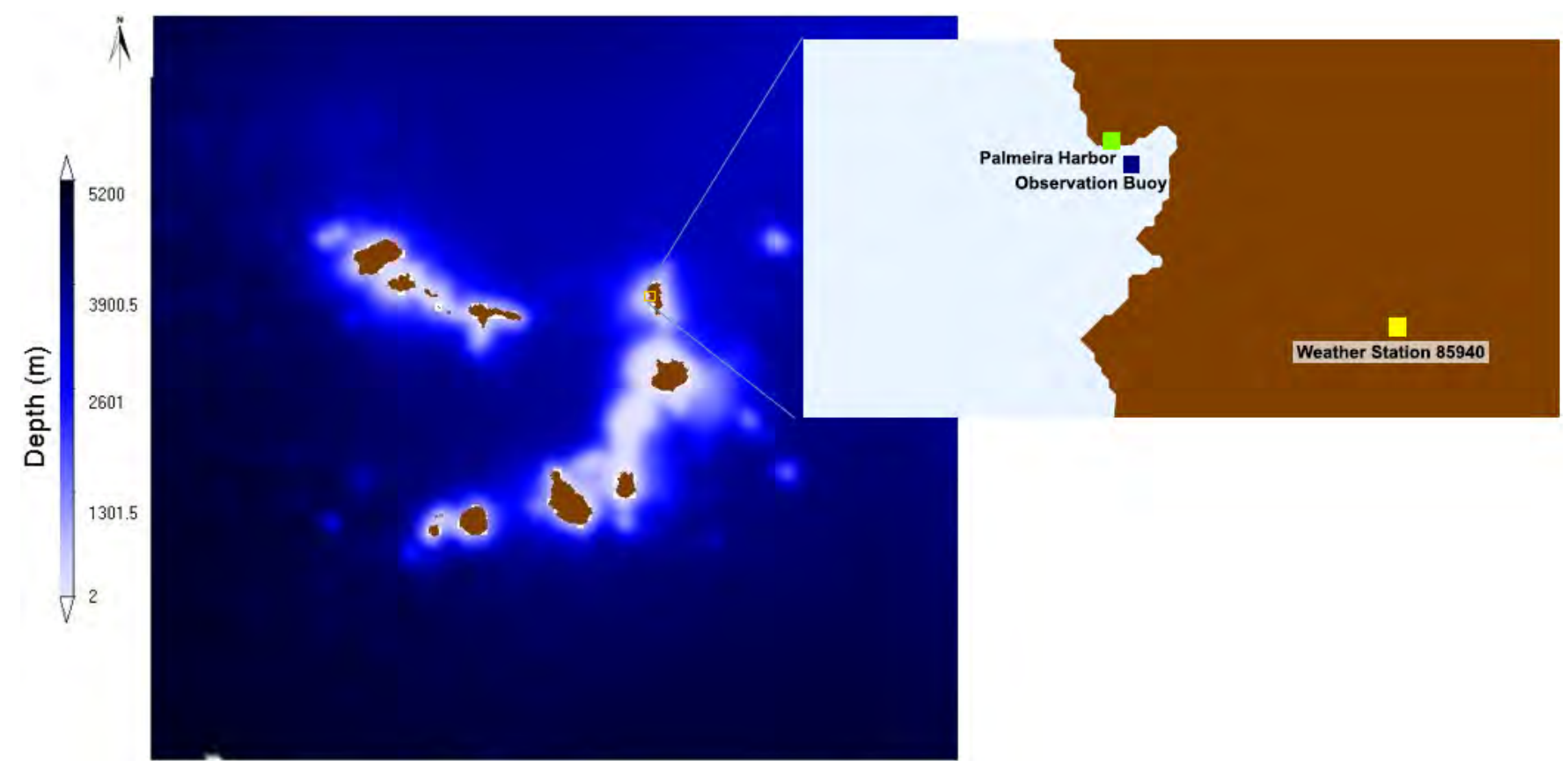

Figure 2 - Bathymetry of the archipelago of Cape Verde and location of the Palmeira Harbour (green dot), of the observation buoy (blue dot), and of the inlan meteorological station (yellow dot).

Figura 2 - Batimetria do arquipélago de Cabo Verde e localização do porto da Palmeira (ponto verde), da bóia de observação (ponto azul) e da estação meteorológica (ponto amarelo) localizada em terra. 


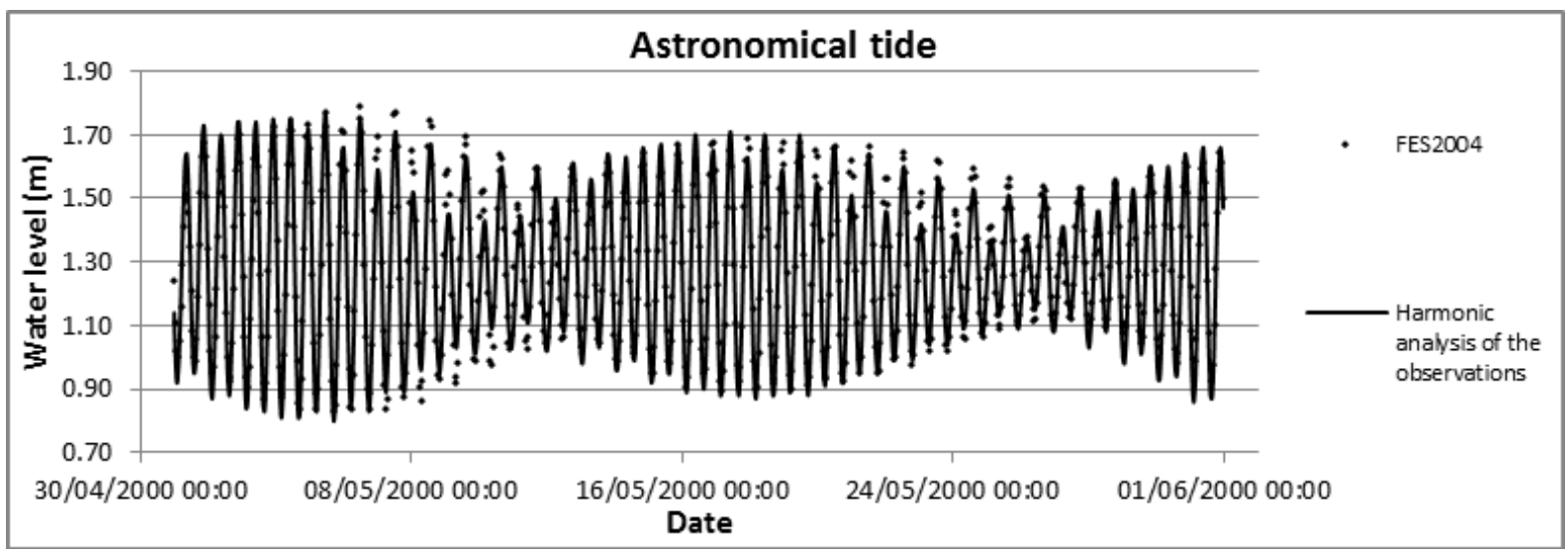

Figure 3 - Comparison of levels reconstitute from FES2004 model (line) harmonics and from harmonics measured at Palmeira harbour.

Figura 3 - Resultados do nível da maré astronômica das componentes da maré do modelo FES2004 (linha) e da análise harmônica das observações (ponto), Porto da Palmeira, Maio de 2000.

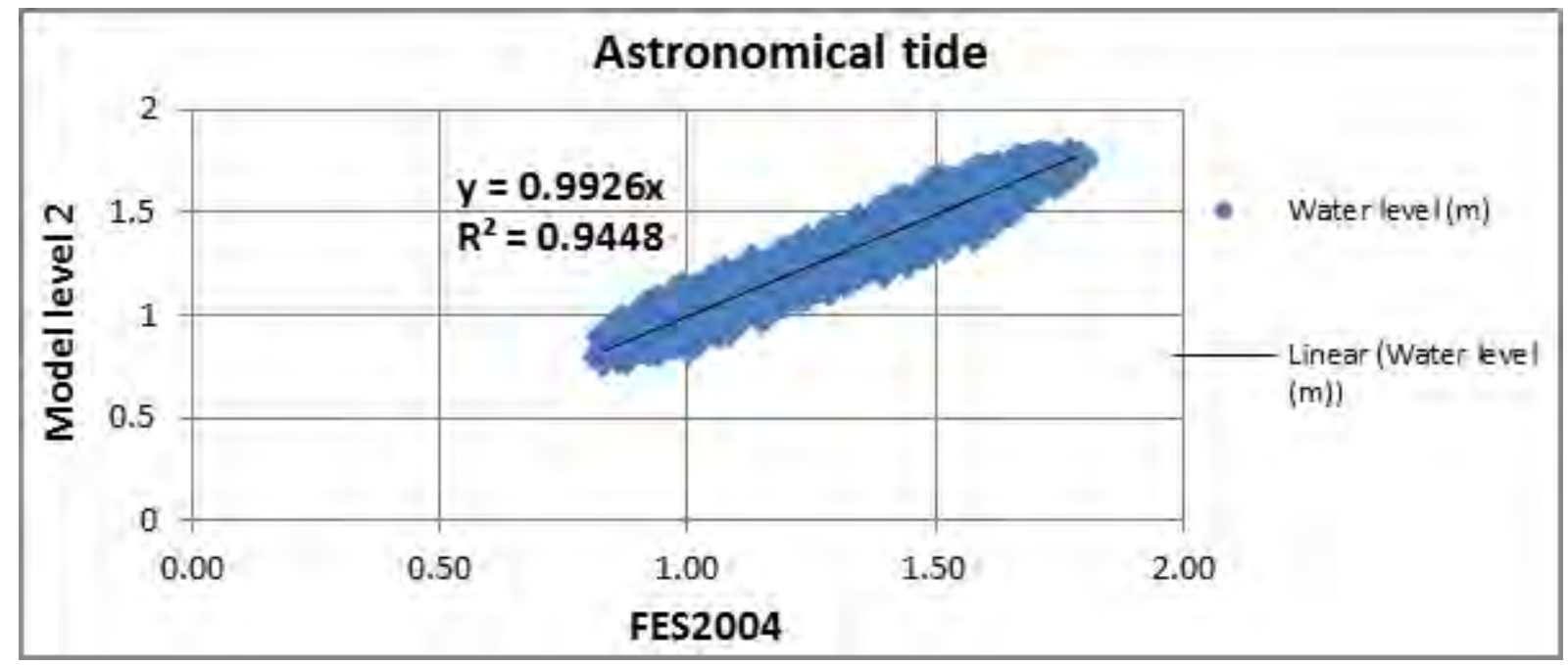

Figure 4 - Correlation between the astronomical tide data and the FES2004, Palm harbour, May 2000.

Figura 4 - Correlação entre a maré astronómica dos dados e o FES2004, para a estação do Porto da Palmeira, Maio de 2000.

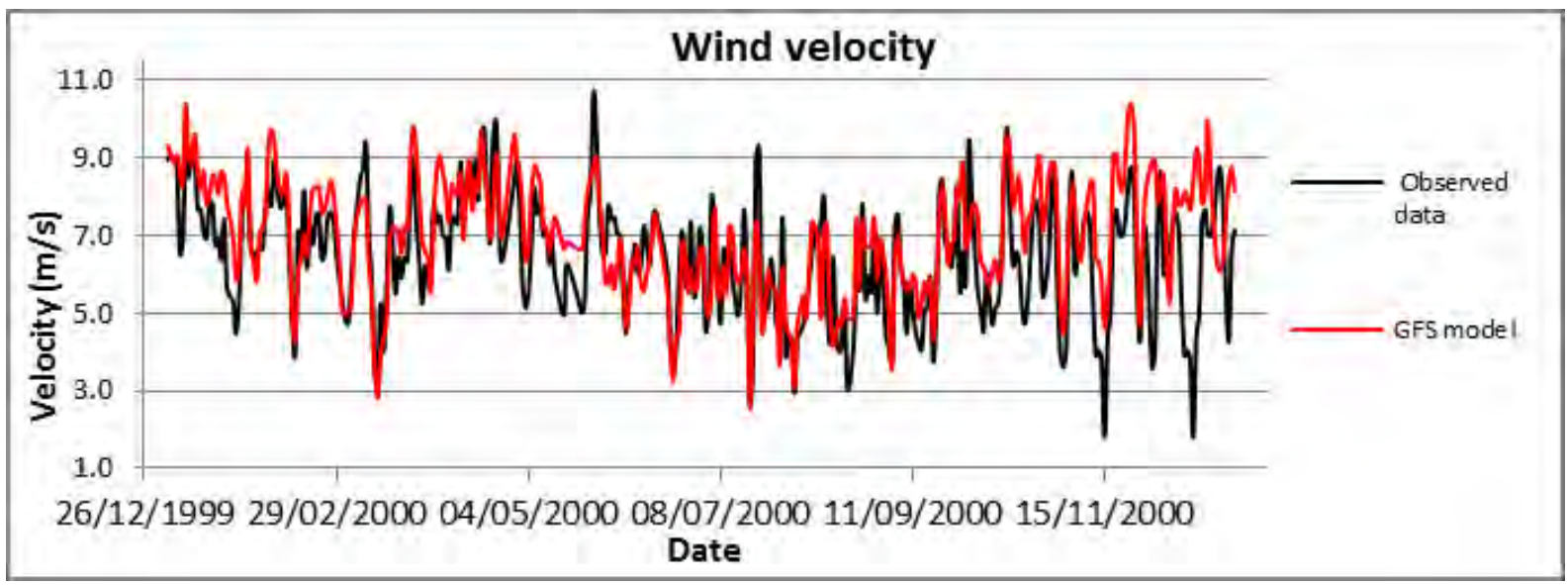

Figure 5 - Time series of daily mean wind velocity, over the 2000 data and GFS weather model at a point on the island of Sal, Cape Verde.

Figura 5 - Séria temporal da velocidade média diária do vento, ao longo do ano 2000, dos dados e do modelo meteorológico GFS num ponto na ilha do Sal, Cabo Verde. 
Wind from GFS model was assessed using the data from the meteorological station located at Sal Island, in the vicinity of the Palmeira harbour (Figure 2). Figure 5 compares time series for the year 2000 showing that the model meteorological captures the main features of the field data and consequently can be used to specify the surface wind stress. The data shows typical wind velocities of the order of $7 \mathrm{~m} / \mathrm{s}$, with higher values in autumn and spring - when velocities often reach $9 \mathrm{~m} / \mathrm{s}$ and lower velocities in summer. The agreement between measured and modelled winds show that GFS model can be used to spec the surface wind fields to the hydrodynamic model.

\subsection{MOHID water modelling system}

MOHID is an open source water modelling system (Neves, 2013) which development is centred at the Instituto Superior Técnico (IST), Universidade de Lisboa, Portugal. It is a modular system based on finitevolumes able to use Cartesian or Sigma vertical grids or a combination of both, including vertical movement of the grid to minimise numerical diffusion associated to internal waves. In this application only one sigma layer is used and consequently the simulation is a $2 \mathrm{D}$ vertically integrated. The versatility of the modular structure allows the model to be used in virtually any free surface flow. It was applied in most Portuguese estuaries to simulate hydrodynamics and water quality (Saraiva et al., 2007; Lopes et al., 2009; Malhadas et al., 2010; Kenov et al, 2012) and in regional seas (Martins et al., 2001). Other applications of MOHID include Galician estuaries such as Ría de Vigo (Taboada et al., 1998; Gomez-Gesteira et al., 1999), and Ría de Pontevedra (Ruiz-Villarreal et al., 2002). Recently, MOHID has been applied to the coast of Southern America (Campuzano et al., 2013). The model software is written in ANSI FORTRAN 95, following object-oriented programming. MOHID includes a graphic user interface with tools for data handling, pre-processing, simulation's management, and post-processing. MOHID uses a semi-implicit algorithm allowing the simulation of complex problems in small computers and can perform parallel computing using openMP or MPI technologies. 3D baroclinic models can be nested into 2D models in order to get the tide at the boundaries. This will be a major use of the 2D tidal model described in this paper which solves the set of equations:

$$
\begin{aligned}
\frac{\partial \eta}{\partial t}+\left[\frac{\partial}{\partial x}(u D)+\frac{\partial}{\partial y}(v D)\right]=0 & \text { Equation 1 } \\
\frac{\partial}{\partial t}(u D)+\left[\frac{\partial}{\partial x}\left(u^{2} D\right)+\frac{\partial}{\partial y}(u v D)\right]-f v D= & \\
\quad=-g D \frac{\partial \eta}{\partial x}+\frac{1}{\rho} \tau^{x}+D\left[\frac{\partial}{\partial x}\left(A \frac{\partial u}{\partial x}\right)+\frac{\partial}{\partial y}\left(A \frac{\partial u}{\partial y}\right)\right] & \text { Equation 2a }
\end{aligned}
$$

$$
\begin{aligned}
& \frac{\partial}{\partial t}(v D)+\left[\frac{\partial}{\partial x}(u v D)+\frac{\partial}{\partial y}\left(v^{2} D\right)\right]-f u D= \\
& =-g D \frac{\partial \eta}{\partial y}+\frac{1}{\rho} \tau^{y}+D\left[\frac{\partial}{\partial x}\left(A \frac{\partial v}{\partial x}\right)+\frac{\partial}{\partial y}\left(A \frac{\partial v}{\partial y}\right)\right] \quad \text { Equation } 2 \mathrm{~b}
\end{aligned}
$$

where $u$ and $v$ are the velocity components along the $\mathrm{x}$ and $\mathrm{y}$ directions; $f$ is the Coriolis parameter, a function of the latitude; $A$ is the coefficient of horizontal viscosity; $\tau^{\mathrm{x}}$ and $\tau^{\mathrm{y}}$ are the wind stresses along the $\mathrm{x}$ and the y directions, respectively; $D$ is the total water column height calculated as $D=h+\eta$, where $h$ is its depth below the reference level and $\eta$ is the elevation above that level (Kantha and Clayson, 2000).

\section{Analysis and discussion of results}

This section starts with the validation of water level using the Palmeira harbour data and describes and discusses the results of the Level 1 model (coarser grid) and Level 2 model (finer grid). Figure 6 shows the comparison between water level observations reconstitute using the harmonic components and the results of the Level 1 model. Both series show identical evolutions, the differences being comparable with the differences between comparable with differences between FES2004 results used to force the model and the observations shown in Figure 3. This agreement proves that the model is propagating the tide correctly in the Level 1. Figure 7 shows the correlation between simulated and observed free surface level time series at Palmeira harbour, shown in Figure 6. The correlation coefficient is $95.68 \%$, slightly higher than the correlation between data and FES2004 results. Figure 8 shows the same comparison for the Level 2 results. The differences are identical and consequently the correlation coefficient is also similar $(95.39 \%)$ showing that to obtain correct water levels is not necessary to have a very high resolution model. High resolution models are in fact required to compute high resolution velocity fields, where topographic features can generate strong velocity gradients with implications on vertical transport of nutrients and chlorophyll production.

\subsection{Spatial analysis of the main tidal constituents}

The time series analysis at the Palmeira harbour has shown that the FES2004 is good enough to specify the tide at the model boundaries and that MOHID is good enough to simulate the tidal propagation within the modelling domain and its results can be used to describe the tidal propagation. In this chapter the spatial analysis of the main tidal components $\left(\mathrm{M}_{2}, \mathrm{~S}_{2}\right.$ and $\left.\mathrm{N}_{2}\right)$ will be performed using the model results. Figures 10 to 12 display maps of amplitudes and phases.

Results show that the three semi-diurnal tidal components $\left(\mathrm{M}_{2}, \mathrm{~S}_{2}\right.$ and $\left.\mathrm{N}_{2}\right)$ propagate northward and that the islands play a major role on the propagation of 


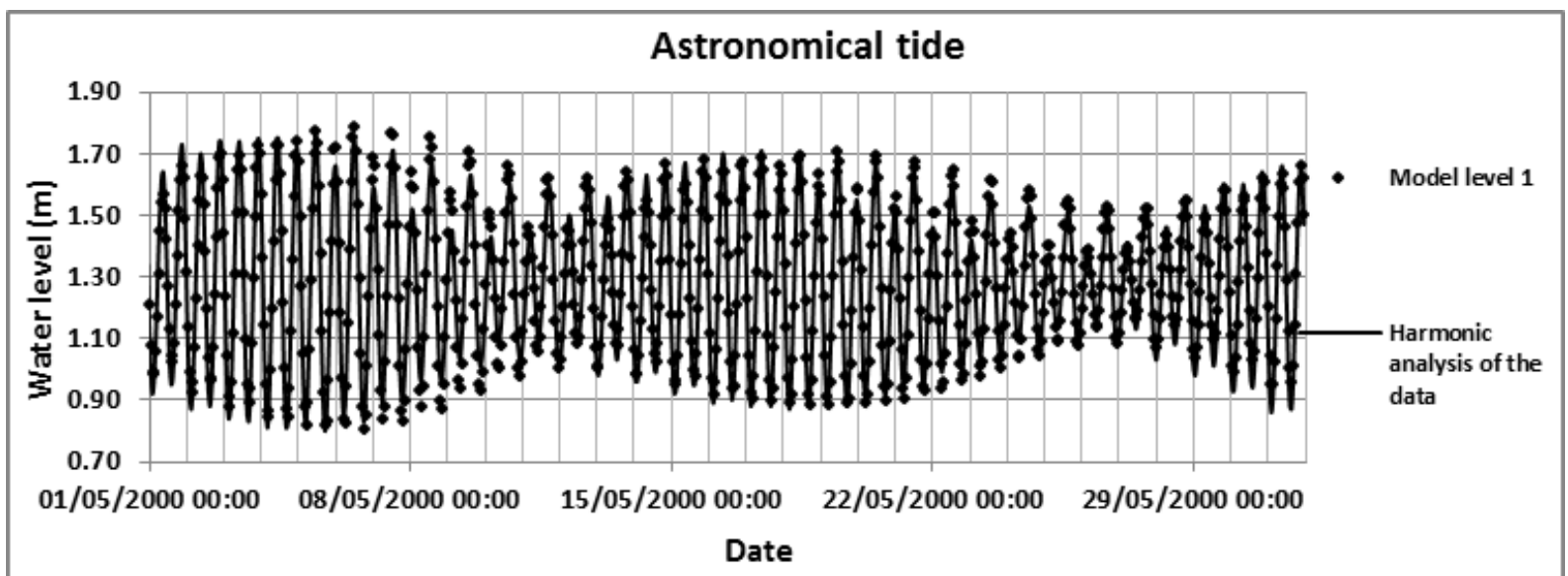

Figure 6 - Results of the tidal model - level 1- and levels reconstitute from observation's harmonics (line) at Palm harbour.

Figura 6 - Resultados do modelo de maré - nível 1 - e níveis reconstituídos (linha) a partir das componentes harmónicas medidas no Porto da Palmeira.

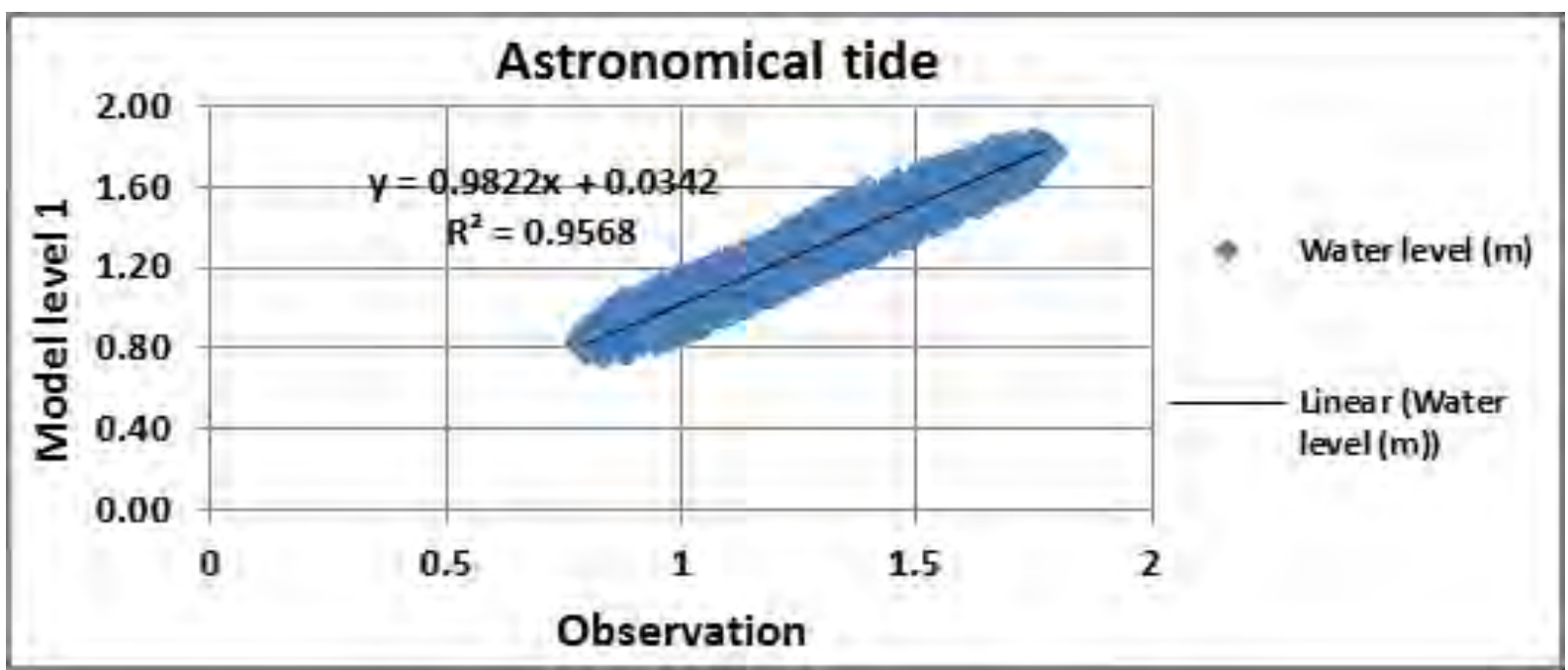

Figure 7 - Correlation between results of the tidal model - level 1 - and levels reconstitute from observation's harmonics at Palmeira harbour.

Figura 7 - Correlação entre resultados do modelo de maré - nível 1 - e níveis reconstituídos a partir das componentes harmónicas observadas em Porto da Palmeira.

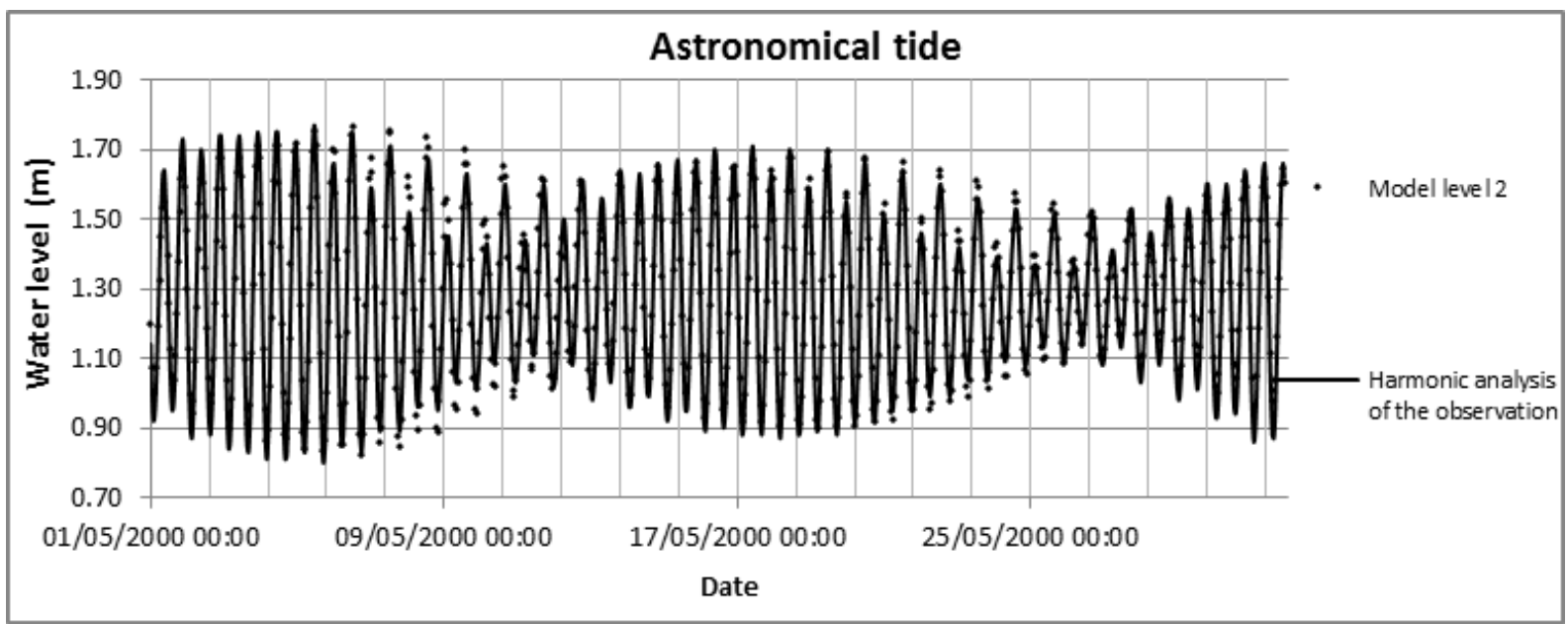

Figure 8 - Results of the tidal model - level 2- and levels reconstitute from observation's harmonics (line) at Palm harbour.

Figura 8 - Resultados do modelo de maré - nível 2 - e níveis reconstituidos (linha) a partir das componentes harmónicas medidas no Porto da Palmeira. 


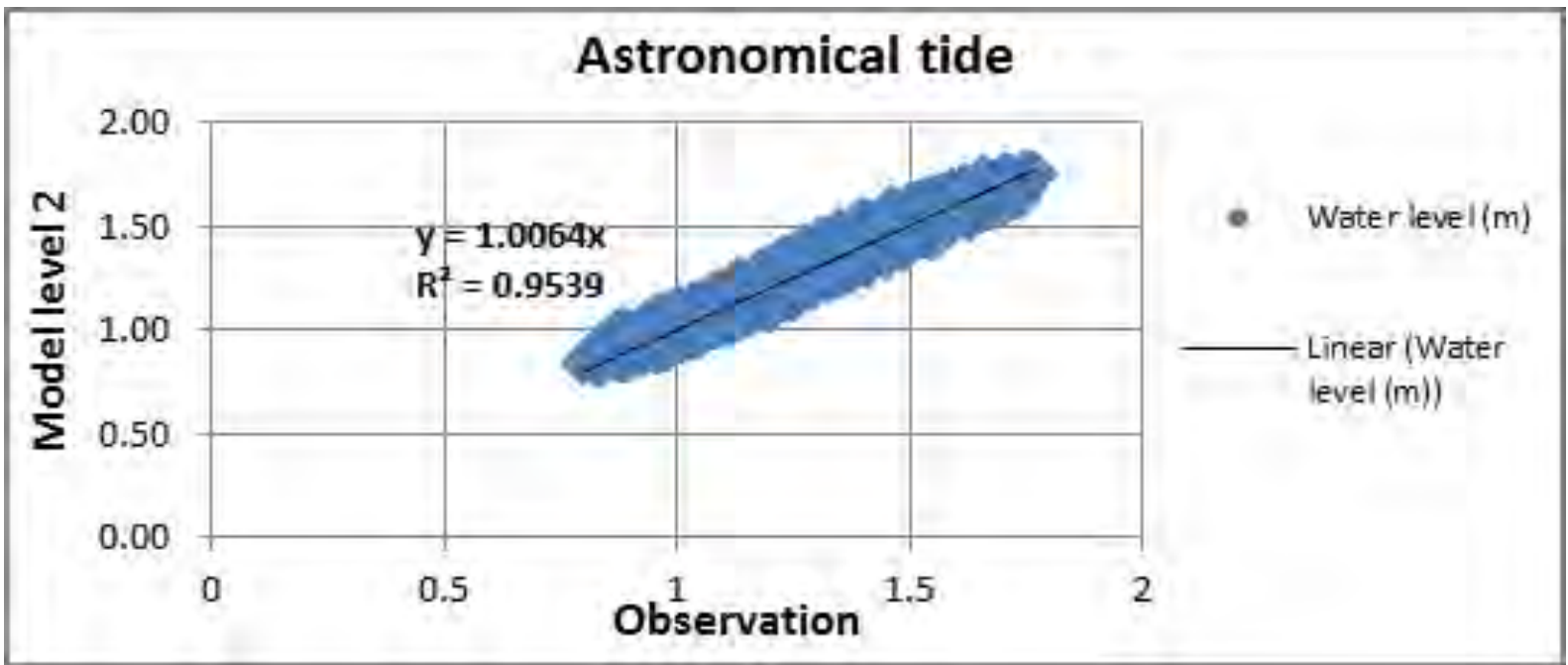

Figure 9 - Correlation between results of the tidal model - level 2 - and levels reconstitute from observation's harmonics at Palmeira harbour.

Figura 9 - Correlação entre níveis calcula pelo modelo de maré - nível 2 - e a partir das componentes harmónicas observadas em Porto da Palmeira.
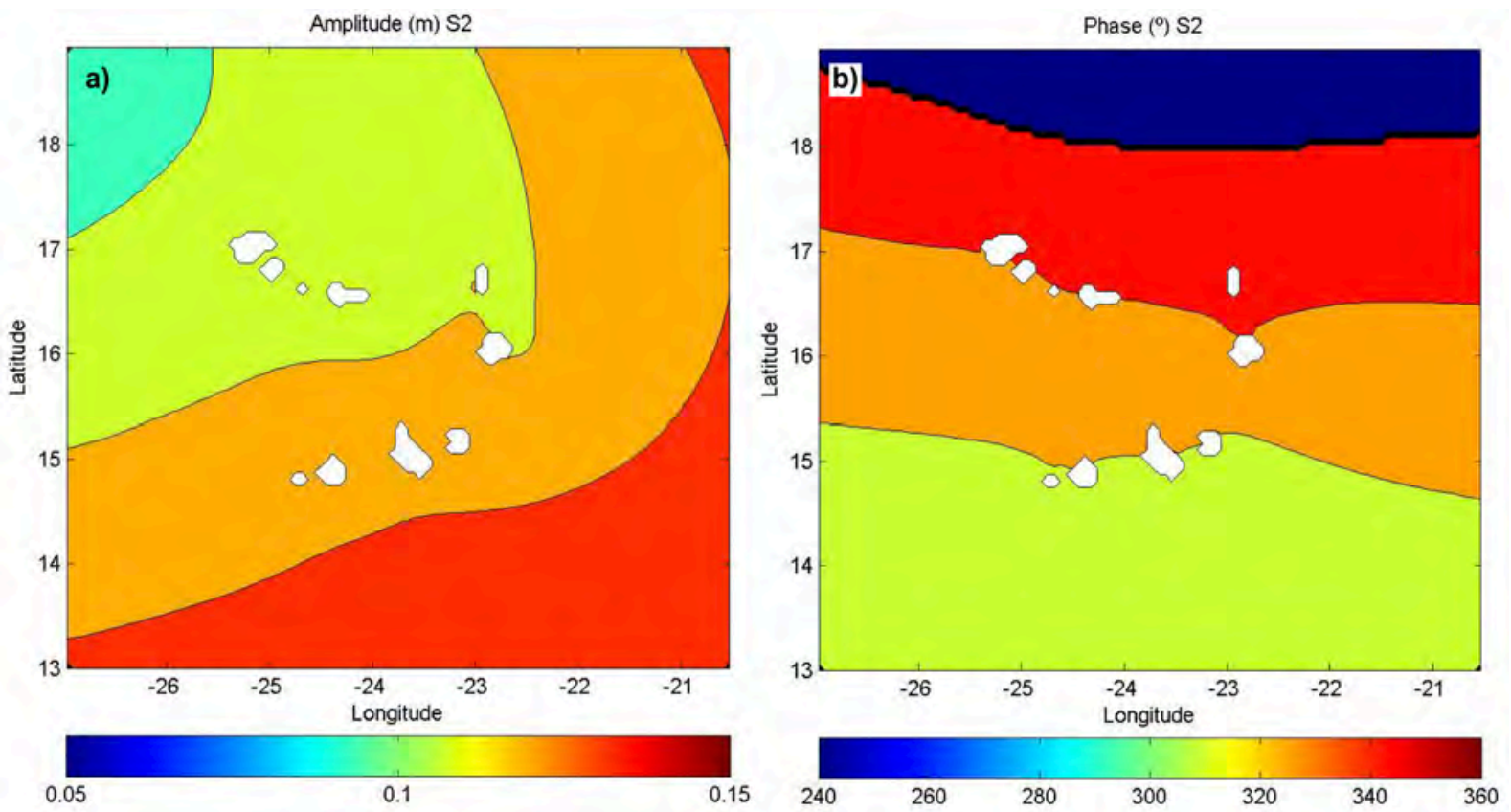

Figure 10 - Maps of co-tidal (a) and co-phase (b) in Cape Verde for $\mathrm{M}_{2}$ constituent.

Figura 10 - Mapas de co-corrente (a) e co-fas (b) Cabo Verde para a componente $M_{2}$.

these components, distorting the isolines and creating regions of higher gradient and thus regions of increased velocity. The $\mathrm{M}_{2}$ amplitude varies between 0.4 along the southern boundary to about $0.24 \mathrm{~m}$ at the northern, while the phase increases from $270^{\circ}$ to $310^{\circ}$. In general, the amplitude of the $\mathrm{N} 2$ and $\mathrm{S} 2$ tidal component show an increase from north to south, in agreement with literature (Lyiard et al., 2006). The N2 and S2 components show little variations in amplitude, ranging between 0.1 and $0.15 \mathrm{~m}$ for $\mathrm{S} 2$, and between 0.05 and 0.1 for N2. Changes in amplitude are observed in transition zones where morphology and depth variations occur due to the presence of the islands.

\subsection{Tidal Circulation}

Figure 13 shows in two situations of maximum flood and ebb current on the $20^{\text {th }}$ May 2000. The figure shows that the tidal flow is globally oriented north-south and that the islands behave as barriers to the flow inducing higher velocities in the channels between the islands and on the extremes of the island groups. Maximum velocities of the order of $30 \mathrm{~cm} / \mathrm{s}$ are computed in the channels between the islands.

Out of the island barrier effect the flow displays low velocity, of the order of $5 \mathrm{~cm} / \mathrm{s}$. This flow pattern shows that the islands play an important role on the local cir 

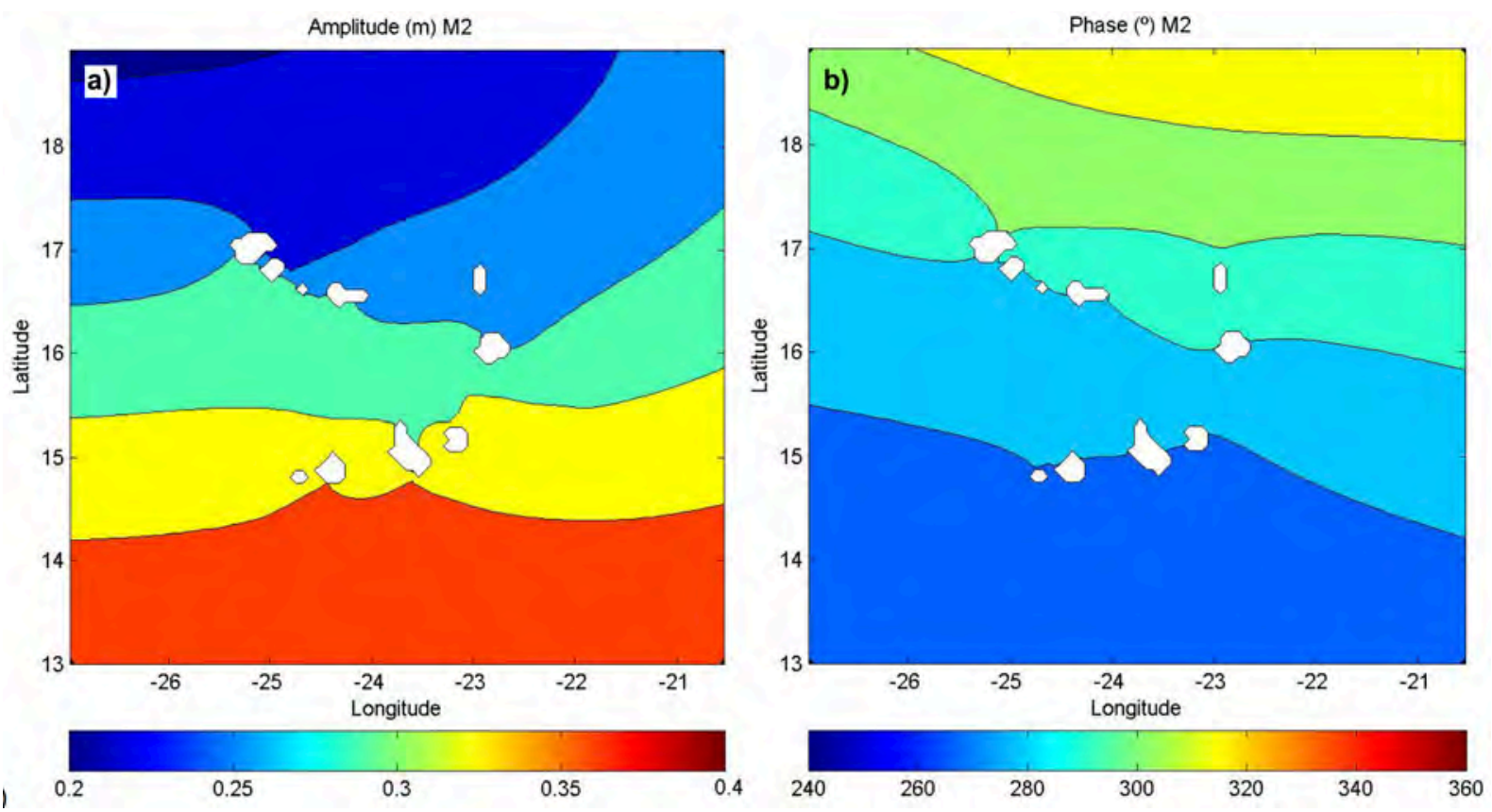

Figure 11 - Maps of co-tidal (a) and co-phase (b) in Cape Verde for $\mathrm{S}_{2}$ constituent.

Figura 11 - Mapas de co-corrente (a) e co-fase (b) em Cabo Verde para a componente $S_{2}$.
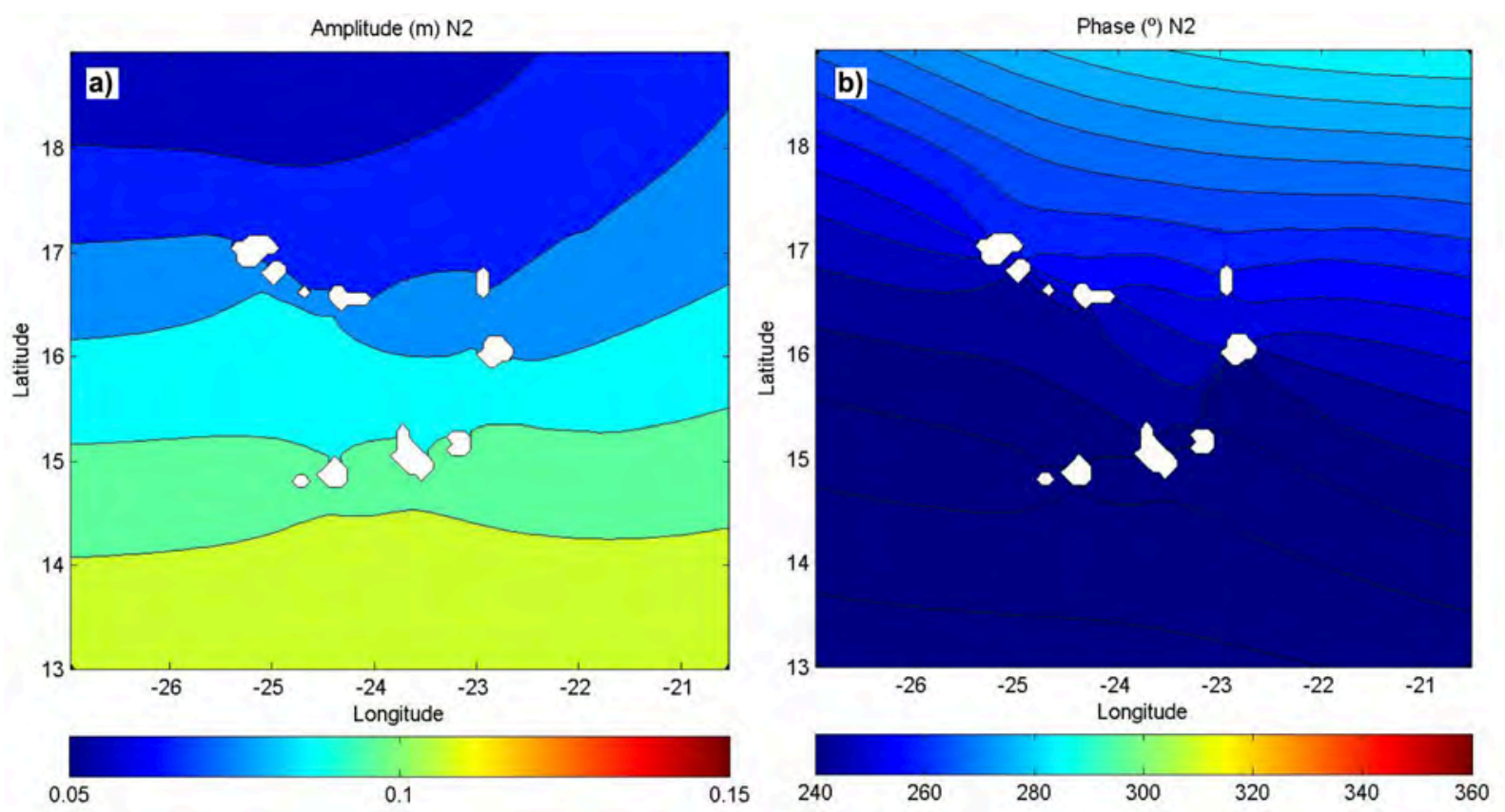

Figure 12 - Maps of co-tidal (a) and co-phase (b) in Cape Verde for $\mathrm{N}_{2}$ constituent.

Figura 12 - Mapas de co-corrente (a) e co-fase (b) em Cabo Verde para a componente $\mathrm{N}_{2}$.

culation and that close to the coast the tide must be considered in any circulation study. The strong acceleration of the flow registered in the vicinity of the islands induces important non-linear effects and strongly increases the local importance of the Coriolis force. As a consequence strong residual currents have to be expected with a tendency for anticyclonic rotation due to Coriolis.

\subsection{Residual Circulation}

The residual velocity is the average of the transient velocity at each point and accounts for the non-linear effects, resulting from the advective and the friction terms. The Coriolis term in presence of a solid boundary also generates residual flow. In deep ocean advection and friction are of secondary importance and 

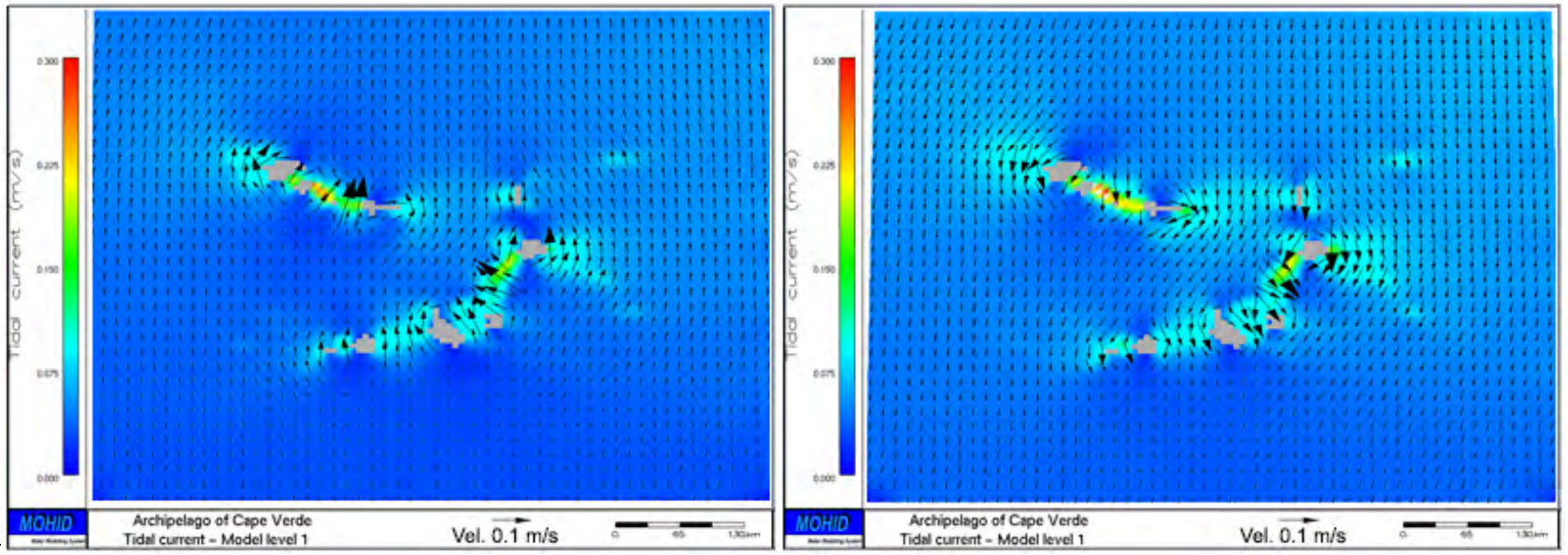

Figure 13 - Tidal currents in the archipelago of Cape Verde (maximum velocity $0.3 \mathrm{~m} / \mathrm{s}$ ) during ebb and flooding $\left(20^{\text {th }}\right.$ May 2000).

Figura 13 - Correntes da maré no arquipélago de Cabo Verde (Máximo da escala $0.3 \mathrm{~m} / \mathrm{s}$ ) em enchente e vazante no dia 20 de Maio de 2000.

consequently residual velocities are very weak. However around islands all non-linear terms get more important.

The advective terms tend to generate eddies in the back side of island, when the water leaves the island. These eddies even if not present in the transient flow, tend to exist in the residual flow since the inertia force is not present when the flow approaches the island. As a consequence around an island in an oscillating tidal flow advection and friction promote the presence of eddies, two on each side of the island. This effect was illustrated by Pingree and Maddock (1980). In presence of earth rotation the Coriolis generates a rotation (anticyclonic in the northern hemisphere) around the island that modulates the four - eddies flow, increasing the residual velocity in two eddies diametrically opposed and decreasing them in the intermediate eddies. The presence of this rotational flow was already pointed out by Huthnance (1973).

Figure 14 shows the residual flow computed by the Level 1 model and displays the tendency for the anticyclonic flow around the islands or groups of islands. This flow is particularly clear around the Windward Islands on the northwest, showing that the Coriolis Effect is the major mechanism generating residual flow. In the same group is also clear the presence of higher velocities in the northwest and southeast corners suggesting that the advective and friction terms are also contributing for the residual flow. The most southern islands present a more complex residual flow pattern which is a consequence of a more complex tidal flow.

The residual flow represents the tendency of the transport. Its knowledge is important to foresee the displacement of pollutants discharged from permanent sources or to understand the sediment transport in regions deep enough to be independent of the wave transport. However the effective transport requires the use of transient models forced by actual wind.

Independently of the practical importance of the residual circulation for coastal management support, this analysis of the residual circulation was an important contribution to validate the model results and thus to increase confidence on the model as a tool to generate knowledge about the hydrodynamic circulation in the Cape Verde Archipelago.

\subsection{Effect of meteorological conditions on currents and water level}

Qualitative and quantitative assessment of the effect of Qualitative and quantitative assessment of the effect of the meteorological conditions were performed by considering scenarios with and without atmospheric forcing. The wind was imposed both in the in the large and local scale models and the differences between the two scenarios were assessed on level 2 model results where shallow areas are. Figure 15 shows a wind velocity fields and pressure distributions (in color) for the $20^{\text {th }}$ May 2000 at $12 \mathrm{pm}$. The figure shows northern winds decreasing southwards with a maximum speed of the order of $11 \mathrm{~m} / \mathrm{s}$ and the atmospheric pressure decreasing from Northwest to Southeast. These wind patterns are identified in the "Livro Branco sobre o Estado do Ambiente em Cabo Verde" as a typical wind field the wind intensity is also identified as being typical in the site http://www.tutiempo.net/clima/Sal/ 04-2000/85940.htm.

Figure 16 compares time series of levels computed with and without wind forcing. The comparison shows that at this location wind forcing generates differences of the order of centimeters. Instantaneous spatial distributions of levels are shown in Figures 17 (a) and 18 (a). These figures show differences of the order of $3 \mathrm{~cm}$, 


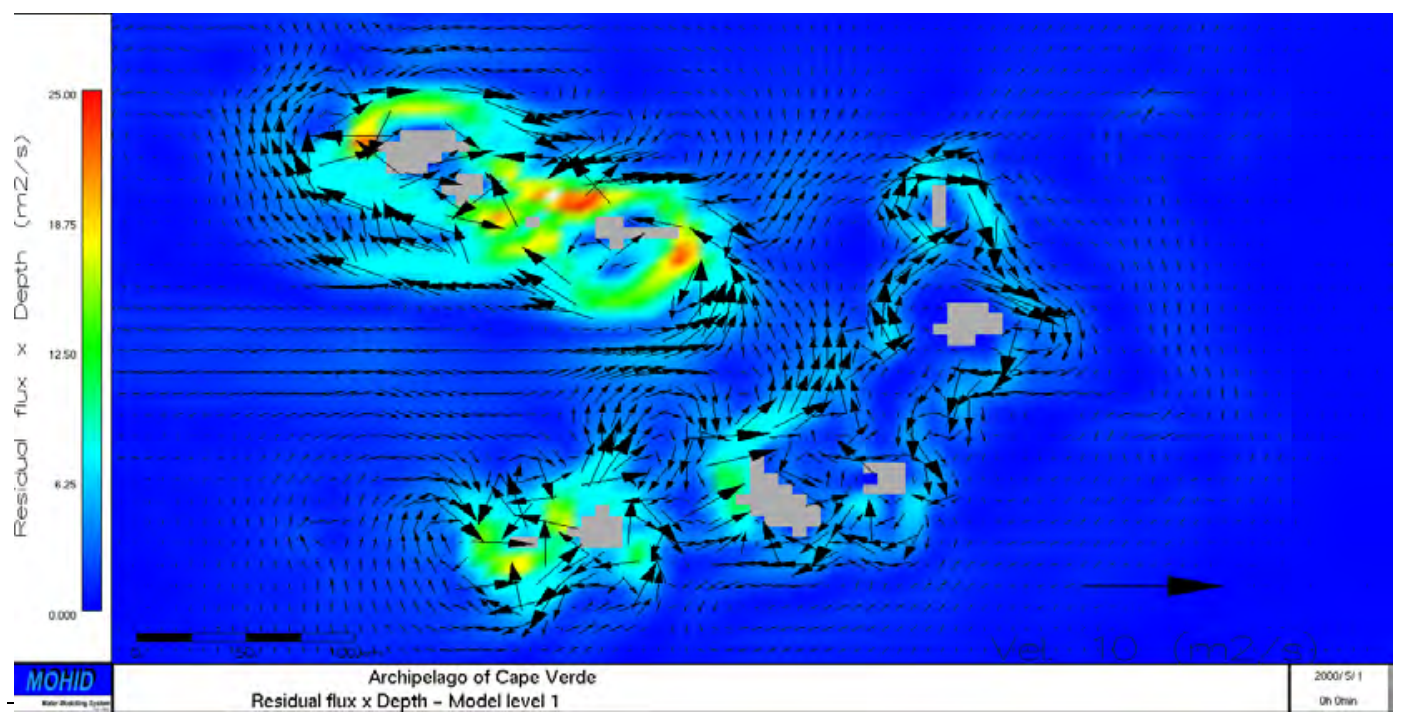

Figure 14 - Residual Flux in level 1 model. It is clear the tendency for an anticyclonic circulation around the islands.

Figura 14 - Velocidade residual no modelo de nível 1. É clara a tendência para a existência de um escoamento anticiclónico em torno das ilhas.

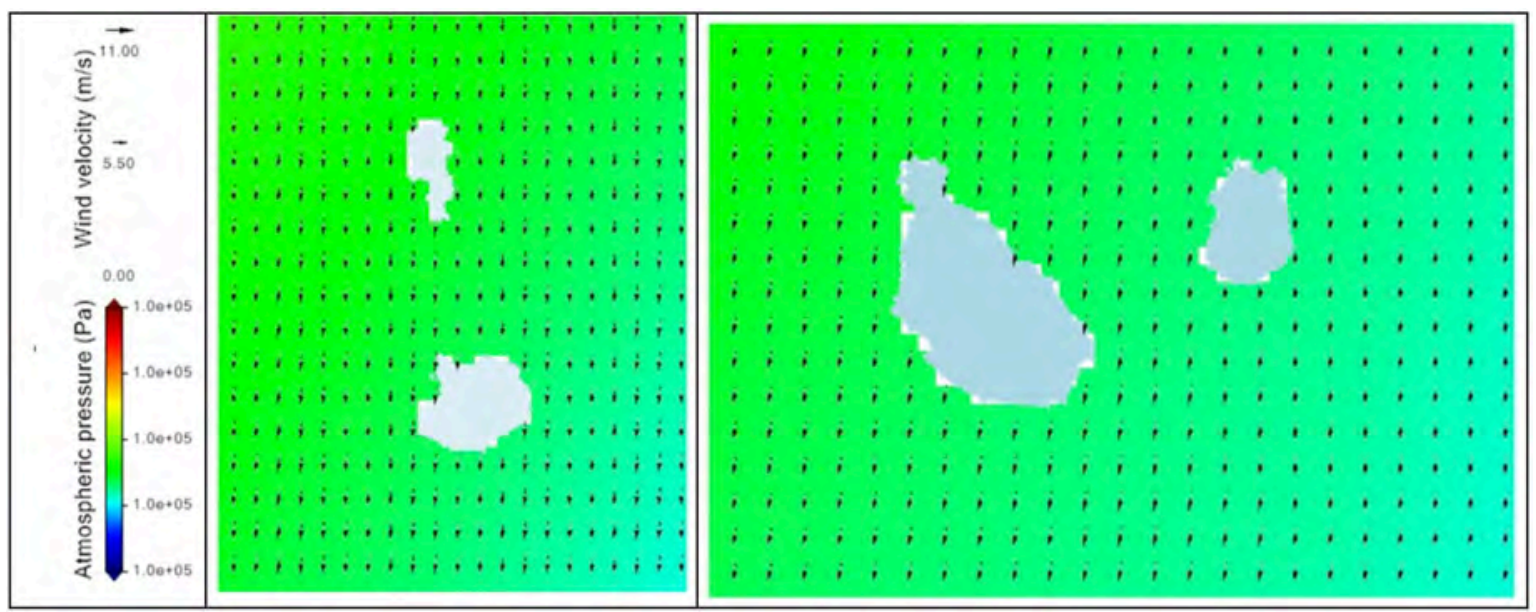

Figure 15 - Results of the tide elevation with (dots) and without (line) meteorological forcing, Palmeira harbour, May 2000.

Figura 16 - Resultados da elevação da maré com (pontos) e sem (linha) forçamento meteorológico, Porto da Palmeira, May de 2000.

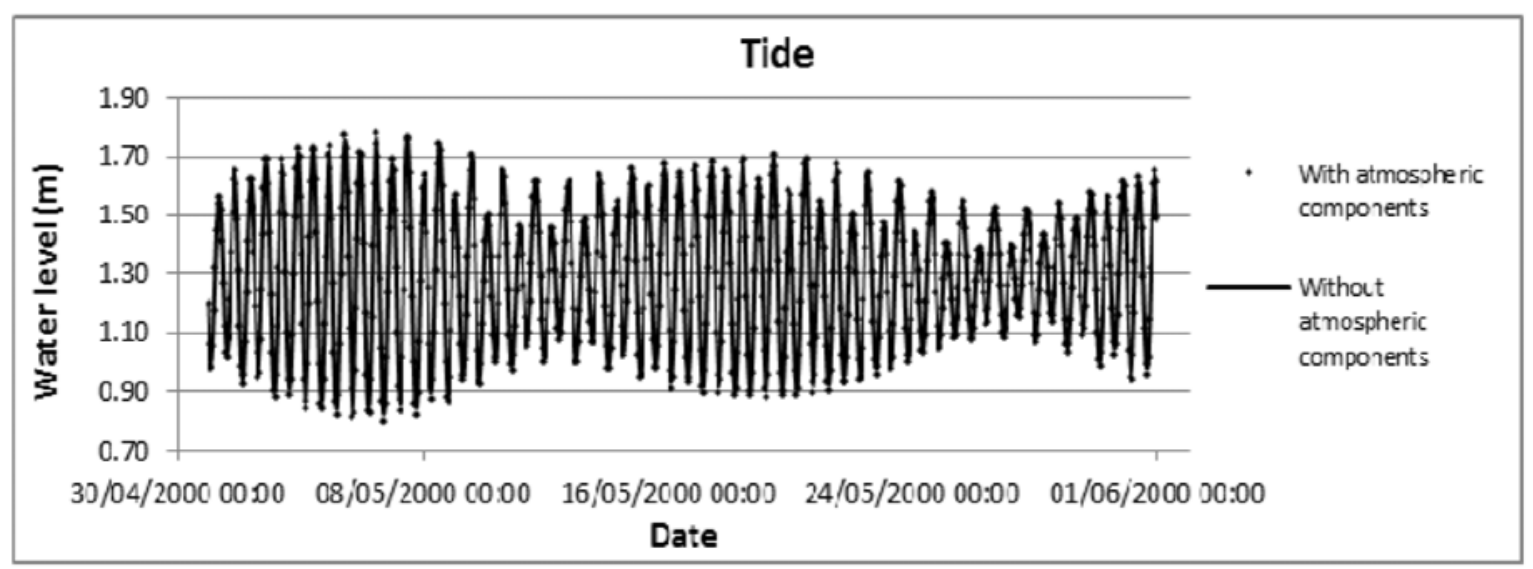

Figure 16 - Results of the tide elevation with (dots) and without (line) meteorological forcing, Palmeira harbour, May 2000.

Figura 16 - Resultados da elevação da maré com (pontos) e sem (linha) forçamento meteorológico, Porto da Palmeira, May de 2000. 

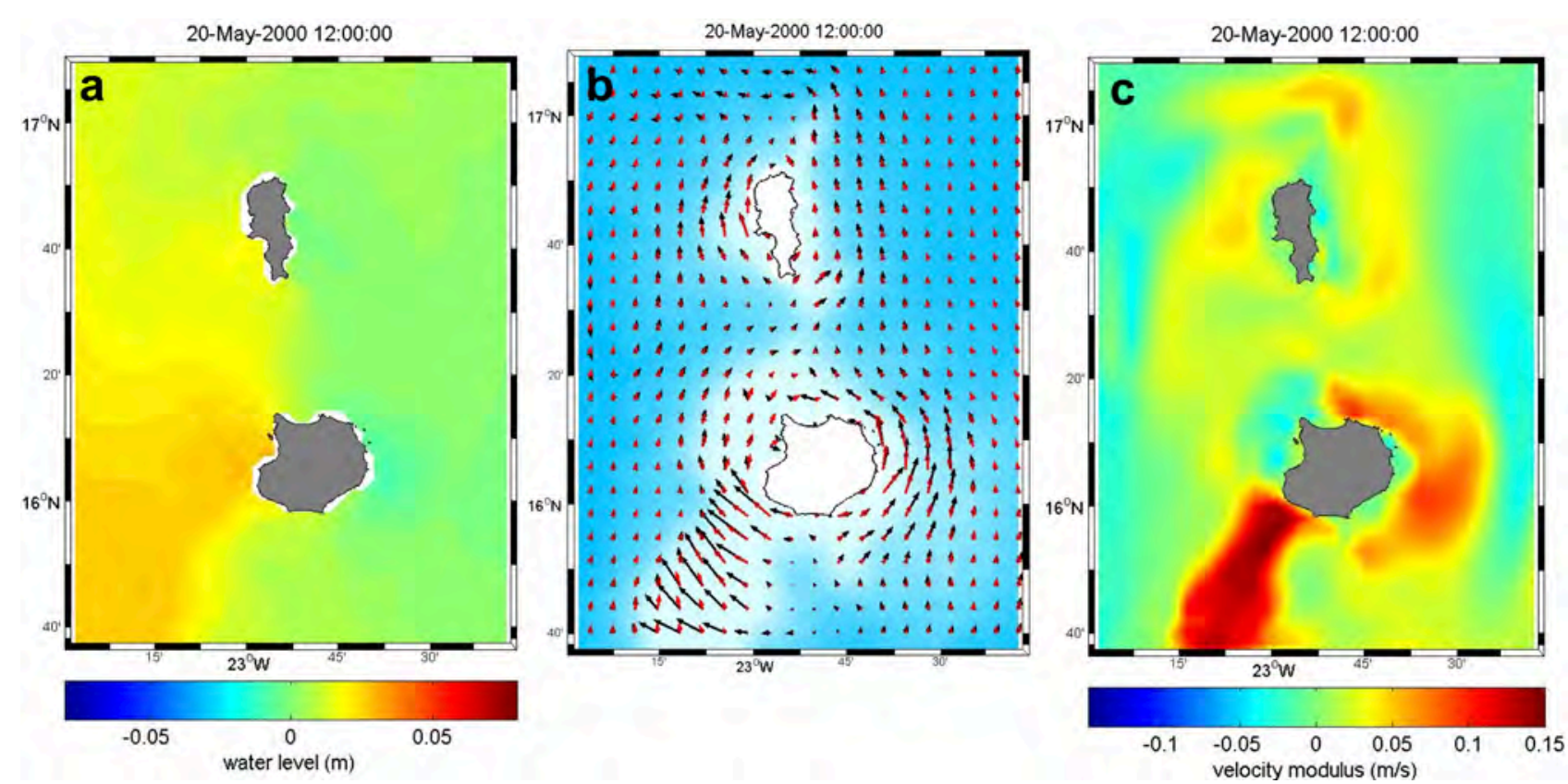

Figure 17 - Comparison of solutions with and without wind forcing in the region of Sal and Boavista islands for the 20 of May 2000 at 12pm: (a) level difference, (b) Velocity vectors (black with and red vector without the atmospheric forcing); (c) velocity intensity difference.

Figura 17 - Comparação da solução com e sem forçamento atmosférico na região da ilha do Sal e Boavista no dia 20 de Maio de 2000 às 12h: (a) diferença de níveis (b) vectores velocidade (preto com e vermelho sem forçamento atmosférico); (c) diferença do módulo da velocidade.
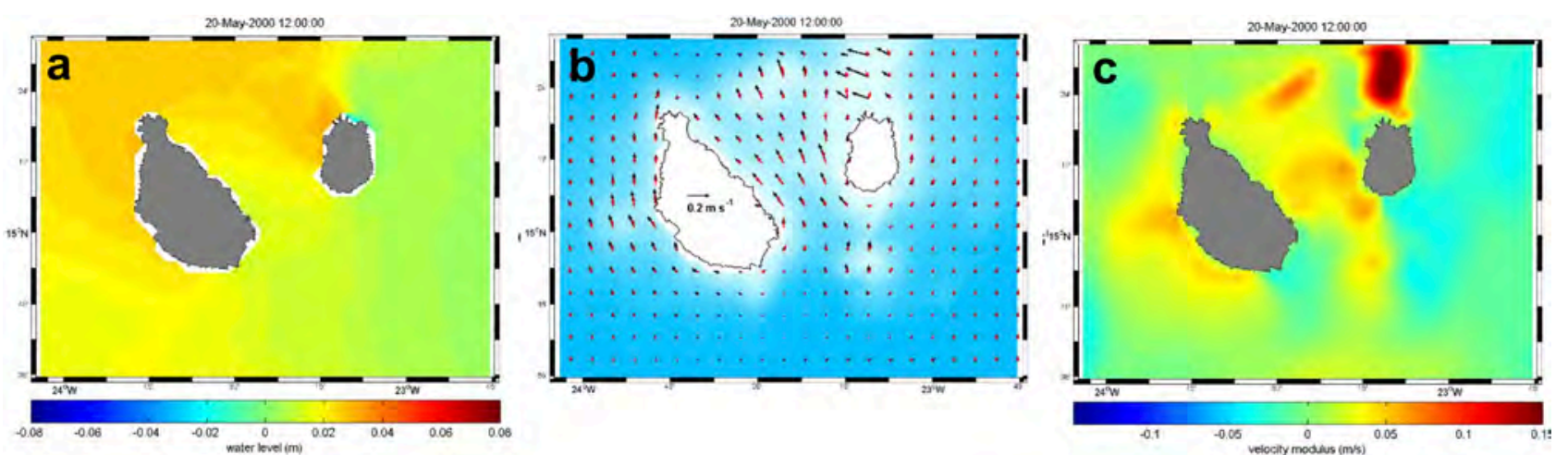

Figure 18 Comparison of solutions with and without wind forcing in the region of Maio and Santiago islands for the 20 of May 2000 at 12pm: (a) level difference, (b) Velocity vectors (black with and red vector without the atmospheric forcing); (c) velocity intensity difference.

Figura 18 - Comparação da solução com e sem forçamento atmosférico na região das ilhas de Maio e de Santiago Boavista no dia 20 de Maio de 2000 às 12h: (a) diferença de níveis (b) vectores velocidade (preto com e vermelho sem forçamento atmosférico); (c) diferença do módulo da velocidade.

for the $20^{\text {th }}$ May at $12 \mathrm{pm}$. High values are located northwest which is consistent with the northeast wind forcing.

The comparison of the velocity field for the scenarios with and without meteorological conditions is presented in Figures 17 (b) and 18 (b). The black arrows represent velocity with meteorological forcing and the red arrows represent velocity without meteorological forcing. The results show that there is a significant difference in the intensity and direction of the currents in the two scenarios over the shallow areas. This effect is enhanced near the coast, as expected, due to the higher effect of wind in shallow areas over the whole water column. The current intensity tend to increase perpendicularly to the wind which is attributed to the Coriolis effect. The maximum current velocity difference between the two scenarios is about $0.15 \mathrm{~m} / \mathrm{s}$, in the shallow regions. In the deeper regions differences are small. However they are expected to be of the same order of magnitude if a 3D baroclinic model was used.

Globally results show that meteorological forcing is a major mechanism generating velocity in the region. Associated to vertical density stratification its importance it is expected to be even higher since it will be respon- 
sible for upwelling and downwelling events around the islands with important biogeochemical consequences.

\section{Conclusions}

This study represents a first step towards a more comprehensive understanding of tidal circulation in the Cape Verde region. The study used all the data available locally and made available by large scale initiatives to study the global ocean and atmosphere dynamics. In the absence of field data model, verification of model results was supported by the agreement with known physical processes. Particularly important was the residual flow pattern around the islands and groups of islands and the modification of the flow pattern by the wind.

The water level observations from the buoy located at Palmeira harbor, dating back to the year 2000 were the only source of data available for quantitative assessment of the water levels computed by the model. These data allowed for the characterization of the major tidal constituents which were very useful to assess the realism of the FES2004 model results to impose the boundary conditions, but also to validate the MOHID model results generated both by the coarser and finer resolution models, with correlations of $95.68 \%$ and $95.39 \%$ respectively. These comparisons show that the fine resolution model was irrelevant to compute tidal levels. Fine resolution model is however important to compute velocities since results of the model show that tidal currents next to the islands are determined by the archipelago morphology, being maxima in the channels between the islands, as expected.

Meteorological forcing has shown to be very important for the flow in regions where the flow is confined to the surface layer, that in a 2D depth integrated model can happen only in the shallow regions around and between the islands, where wind driven currents can be more important than the tidal currents. This means that in stratified regions where the wind effect is confined to the surface by buoyancy wind circulation is very important and thus the next step of this work must be based on a 3D baroclinic model.

This work is an important step for the understanding of the general characteristics of the tidal currents in the archipelago of Cape Verde that is necessary step for the understanding of the relative importance of each process responsible for the flow in more comprehensive hydrodynamic studies.

The residual flow pattern is already very important to support the management of anthropogenic discharges, and globally the results are of great importance to design the field experiments that must precede any water quality study or to support spatial planning and tourism development in Cape Verde.

\section{References}

Antunes, A. G. (2008) - Riscos Geológicos associados às construções nas encostas e leito das ribeiras no Concelho de São Lourenço dos Órgãos. 53p., Trabalho de Licenciatura, Instituto Superior de Educação (ISE), Cidade da Praia, Cabo Verde. Available on-line at http://www.portaldo conhecimento.gov. cv/handle/10961/1728

Aumont, O.; Orr, J. C.; Jamous, D.; Monfray, P.; Marti, O.; Madec, G. (1998) - A degradation approach to accelerate simulations to steady-state in a 3-D tracer transport model of the global ocean. Climate Dynamics, 14(2):101-116. DOI: $10.1007 /$ s003820050212

Campuzano, F.; Nunes, S.; Malhadas, M.; Neves, R. (2010) Modelling hydrodynamics and water quality of Madeira Island (Portugal). GLOBEC International Newsletter (ISSN: $1862-$ 4022), 16(1):40-42, Global Ocean Ecosystem Dynamics (GLOBEC), Plymouth Marine Laboratory (PML), Plymouth, United Kingdom. Available on-line at: http://www.mohid.com/ PublicData/Products/Papers/Globec_campuzanofjetal.pdf

Campuzano, F. J.; Mateus, M. D.; Leitão, P. C.; Leitão, P. C.; Marín, V. H.; Delgado, L. E.; Tironi, A.; Pierini, J. O.; Sampaio, A. F. P.; Almeida, P.; Neves, R. (2013) - Integrated coastal zone management in South America: A look at three contrasting systems. Ocean \& Coastal Management, 72:22-35. DOI: 10.1016/j.ocecoaman.2011.08.002

Cancino, L.; Neves, R. (1999) - Hydrodynamic and sediment suspension modelling in estuarine systems Part I: Description of the numerical models. Journal of Marine System, 22(2-3):105116. DOI: 10.1016/S0924-7963(99)00035-4

DGA (2004) - Livro Branco sobre o Estado do Ambiente em Cabo Verde. 227p., Direcção Geral do Ambiente (DGA), Ministério do Ambiente Agricultura e Pescas, Praia, Cape Verde. Available on-line at http://www.sia.cv/index.php/documentacao-mainmenu/ category/3-relatorios-e-estudos?download=13:1ivro-branco

EMC (2003) - NCEP Office Note 442 - The GFS Atmospheric Model. 14p., Environmental Modeling Center (EMC), National Oceanic and Atmospheric Administration National Weather Service, Washington, D.C., U.S.A. Available on-line at http://www.lib.ncep.noaa.gov/ncepofficenotes/files/on442.pdf

Ferreira, J. G.; Simas, T.; Nobre, A.; Silva, M. C; Schifferegger, K.; Lencart-Silva, J. (2003) - Identification of Sensitive Areas and Vulnerable Zones In Transitional and Coastal Portuguese Systems. Application of the United States National Estuarine Eutrophication Assessment to the Minho, Lima, Douro, Ria de Aveiro, Mondego, Tagus, Sado, Mira, Ria Formosa and Guadiana systems. 168p., INAG/IMAR, Lisboa, Portugal. ISBN: 9729412669. Available on-line at http://www.eutro.org/ documents/NEEA Portugal.pdf

Gomez-Gesteira, M.; Montero, P.; Prego, R.; Taboada, J. J.; Leitão, P.; Ruiz-Villarreal, M.; Neves, R.; Pérez-Villar, V. (1999) - A two-dimensional particle tracking model for pollution dispersion in A Coruña and Vigo Rias (NW Spain). Oceanologica Acta, 22(2):167-177. DOI: 10.1016/S0399-1784(99)80043-7

Huthnance, J. M. (1973) - Tidal current asymmetries over the Norfolk sand-banks. Estuarine and Coastal Marine Science, 1(1):89-99. DOI: 10.1016/0302-3524(73)90061-3

Kantha, L. H.; Clayson, C. A. (2000) - Numerical models of oceans and oceanic processes. 940p., Academic Press, San Diego, CA, U.S.A. ISBN: 9780124340688

Kenov, I. A.; Garcia, A. C.; Neves, R. (2012) - Residence time of water in the Mondego estuary (Portugal). Estuarine, Coastal and Shelf Science, 106:13-22. DOI: 10.1016/j.ecss.2012.04.008

Lopes, J. F.; Cardoso, A. C.; Moita, M. T.; Rocha, A. C.; Ferreira, J. A. (2009) - Modelling the temperature and the phytoplankton distributions at the Aveiro near coastal zone, Portugal. 
Ecological Modelling, 220(7):940-961. DOI: 10.1016/ j.ecolmodel.2008.11.024

Lyard, F.; Lefevre, F.; Letellier, T.; Francis, O. (2006) - Modelling the global ocean tides: modern insights from FES2004. Ocean Dynamics, 56(5-6):394-415. DOI: 10.1007/s10236-006-0086-x

Malhadas, M. S.; Leitão, P. C.; Silva, A.; Neves, R. (2009) - Effect of coastal waves on sea level in Óbidos Lagoon, Portugal. Continental Shelf Research, 29(9):1240-1250. DOI: 10.1016/j.csr.2009.02.007

Martins, F.; Leitão, P.; Silva, A.; Neves, R. (2001) - 3D modelling in the Sado estuary using a new generic vertical discretization approach. Oceanologica Acta, 24(Suppl. 1):51-62. DOI: 10.1016/S0399-1784(01)00092-5

Neves, R. (2013) - The MOHID concept. In: M. Mateus \& R. Neves, Ocean modelling for coastal management - Case studies with MOHID, pp.1-11, IST Press, Lisboa Portugal. ISBN: 9789898481245. Available on-line at http://www.mohid.com/ publicdata/products/bookpapers/2013_mohidbook_c01.pdf
Pawlowicz, R.; Beardsley, B.; Lentz, S. (2002) - Classical tidal harmonic analysis including error estimates in MATLAB using T_TIDE. Computers \& Geosciences, 28(8):929-937. DOI: $1 \overline{0.1016 / S 0098-3004(02) 00013-4 ~}$

Pingree, R. D.; Maddock, L. (1980) - Tidally induced residual flows around an island due to both frictional and rotational effects. Geophysical Journal of the Royal Astronomical Society, 63(2):533-546. DOI: 10.1111/j.1365-246X.1980.tb02636.x

Ruiz-Villarreal, M.; Montero, P.; Taboada, J. J.; Prego, R.; Leitão, P. C.; Pérez-Villar, V. (2002) - Hydrodynamic model study of the Ria de Pontevedra under estuarine conditions. Estuarine, Coastal and Shelf Science, 54(1):101-113. DOI: 10.1006/ ecss. 2001.0825

Taboada, J. J.; Prego, R.; Ruiz-Villarreal, M.; Gomez-Gesteira, M.; Montero, P.; Santos, A. P.; Pérez-Villar, V. (1998) - Evaluation of the seasonal variations in the residual circulation in the Ría of Vigo (NW Spain) by means of a 3D baroclinic model. Estuarine, Coastal and Shelf Science, 47(5):661-670. DOI: 10.1006/ecss. 1998.0385 